\title{
Article \\ Efficacy of some botanical extracts for eco-friendly management of aphid in yard long bean
}

\author{
Jesmin Ara Khatun ${ }^{1 *}$, Md. Abul Kalam Azad ${ }^{1}$ and Md. Sultan Ahmed ${ }^{2}$ \\ ${ }^{1}$ Institute of Environmental Science (IES), University of Rajshahi, Rajshahi-6205, Bangladesh \\ ${ }^{2}$ Entomology Division, Bangladesh Agricultural Research Institute (BARI), Gazipur-1701, Bangladesh
}

*Corresponding author: Jesmin Ara Khatun, Institute of Environmental Science (IES), University of Rajshahi, Rajshahi-6205, Bangladesh. E-mail: jesminara81@gmail.com

Received: 16 March 2020/Accepted: 14 May 2020/ Published: 30 May 2020

\begin{abstract}
The study was conducted to find out less hazardous, environmental friendly and locally available botanicals to control bean aphid. Seven plant extracts viz., neem leaves (Azadirachta indica), lemon outer shell (Citrus aurantifolia), wild sunflower (Helianthus petiolaris), water gourd (Lageneria siceraria), green mango (Mangifera indica), bitter gourd (Momordica charanter), fire tree (Delonix regia) and detergent (5 g trix/L) were prepared to control the aphid infestation in yard long bean (variety kagarnatki) in the field. About $100 \mathrm{~g}$ of fresh plant parts of each were boiled in one liter of water at $55^{\circ} \mathrm{C}$ for 5 minutes. Then rest the sample for one hour. The solutions were filtered and kept in clean glass bottles. The extract was kept in refrigerator at $4^{0} \mathrm{C}$ until use. Then the extracts were sprayed at an interval of 3 days in the experimental field of yard long bean. The damage potential of aphid was counted at every 3 days in a week. Results of this study showed that plant extracts were effective against aphid infestation in yard long bean. Similarly, yield results corresponded positively with the effectiveness of the treatments. In this study, fire tree \&water gourd treatment showed 95$98 \%$ control of yard long bean aphid, whereas a high number of aphids were found in the bitter gourd treatment (21.27 \pm 5.985278$)$. Fire tree and water gourd treatment kept about 21.27 times better performance than that of bitter gourd treatment. Water gourd and fire tree has antibacterial, antifungal, antimicrobial properties and toxic activity to control insect pests. So, the present finding suggests that the use of plant extracts of fire tree and water gourd treatment to be very effective botanicals to control aphids of yard long bean in Bangladesh.
\end{abstract}

Keywords: plant extracts; bean aphid; effective; botanical pesticides

\footnotetext{
1. Introduction

Yard long bean (Vigna unguiculata subsp. sesquipedalis (L.) Walp) is originated in West Africa and it is a vigorous climbing vine. The plant is subtropical/tropical and most widely grown in the warmer parts of South Asia, South-East Asia, Southern China and India. Yard long bean is an important leguminous vegetable grown very profitably all over Bangladesh. It is extensively grown in kharif season when there is shortage of vegetables supply in the market. It is one of the vegetables having exporting potential in Bangladesh. It is a highly nutritive vegetable containing a good amount of digestible protein both in pods (23.5-26.3\%) and in leaves (Ano and Ubochi, 2008). A serving of $100 \mathrm{~g}$ of yard long bean contains 50 calories, $9.0 \mathrm{~g}$ of total carbohydrates, $3.0 \mathrm{~g}$ of proteins, $0.2 \mathrm{~g}$ total fat and $0.8 \mathrm{~g}$ of minerals (Anonymous, 2013).

The cultivation of this crop faces various problems including the pest management (Rashid, 1993). Yard long bean is especially attractive to aphids (Aphis craccivora, Myzus persicae and Aphis gossypii), green stink bug (Nezara viridula) and red spider mite (Tetranychus spp.). The insect pests have been reported as one of the serious problems to yard long bean cultivation in the country (Grubben, 1993). Aphid, the most destructive pest, causes damage by sucking sap from flowers, buds, pods and tender branches of the plants and reduces the viability of plant (Thaker et al., 1984).
} 
There have been a large number of plant products, which possess pesticidal properties and have been used successfully for controlling various pest in field and laboratory conditions (Bajpai and Sehgal, 2000). Bangladesh and many other Asian countries are rich in plant products and traditionally used by the rural inhabitants for medicinal purpose and in some instance as preparations for insect control (Talukder and Howse, 1993). Water gourd leaves contain cucurbitacin B. Cucurbitacin is highly toxic to animals and mammals, it also poisonous. (The Wealth of India, 2004). The flower of fire tree acts as acid base indicator. The fire tree has many beneficial bioactivities such as antifungal, antibacterial, antioxidant, antiemetic, larvicidal, hepatoprotective, anti-diarrhoeal, anti-inflammatory, antimalarial, anthelmintic, antiarthritic, wound healing and anticarcinogenic potential along with their experimental evidence and mode of action (Mariajancyrani and Chandramohan, 2013). Botanical pesticides tend to have broad spectrum activity, are relatively specific in their mode of action, and easy to process and use in farm-level. They are also safe for higher animals and the environment (Anonymous, 1991). Plants are rich sources of natural substances that can be utilized in the development of environmentally safe methods for insect control (Sadek, 2003). Botanical products like tobacco extract, neem oil and extract, which can be easily and cheaply collected in rural Bangladesh, have been found promising and useful for the control of sucking insect pests. Although they have been found promising for protection of stored products but botanicals have received little attention for field crops in Bangladesh. Bangladesh is rich in plant biodiversity. This research in botanical pesticides has a good scope of study to find out different indigenous plants of Bangladesh to produce an eco-friendly plant-based pesticide for sustainable aphid management of yard long bean in the field. This study was conducted to find out the suitable botanical pesticides for the control of aphid control in yard long bean.

\section{Materials and Methods}

\subsection{Collection of botanicals}

Seven plants were collected from the research field of the campus of Rajshahi University, Rajshahi, Bangladesh. After collection, fresh plant parts were washed in running tap water and boiled in freshwater at $55^{\circ} \mathrm{C}$ for 5 minutes.

\section{Baseline information of the treatments}

\begin{tabular}{|l|l|l|}
\hline Common Name & Scientific Name & Plantparts used \\
\hline Wild Sunflower & Helianthus petiolaris & Flowers \\
\hline Lemon outer shell (Lebu khosa) & Citrus aurantifolia & Fruits shell \\
\hline Neem & Azadirachta indica & Leaves \\
\hline Water guard & Lageneria siceraria & Leaves \\
\hline Bitter guard & Momordica charanter & Fruits \\
\hline Green Mango & Mangifera indica & Fruits \\
\hline Fire tree & Delonix regia & Flowers \\
\hline Detergent (5g trix/L) & & \\
\hline
\end{tabular}

\subsection{Preparation of experimental plot}

The field experiment was conducted at Botanical Pesticides Research Field of Institute of Environmental Science (IES), University of Rajshahi. The experimental land was first opened with a country plough. Ploughed soil is then brought into desirable final tilt condition by five operations of pouching followed by laddering. The stubbles of the crops and uprooted weeds were removed from the field and the land was properly leveled for planting of yard long bean. To support the plant growth cow-dung, Triple Super Phosphate (TSP), Muriate of Potash (MP) and Urea fertilizers were applied at recommended dose. The whole amounts of fertilizers were used as the basal dose during pit preparation. Then, the seeds were sowing in the pit of experimental plot. The plot was irrigated with fresh water when necessary and other intercultural operations were also done properly.

\subsection{Preparation of botanical pesticides}

About $100 \mathrm{~g}$ of each fresh plant parts were boiled in one liter of water. Then solutions were filtered with a clean filter and kept in glass bottles. The water extracts was kept in refrigerator at $4^{0} \mathrm{C}$ until use.

\subsection{Method of application}

Botanical pesticides were sprayed in yard long bean in the experimental field at an interval of 3 days with the help of knap sack sprayer. One control treatment of without botanical pesticide was maintained in this experiment where only clean water was sprayed. 


\subsection{Pest attack counting}

The pest attack was monitored regularly and the damage potential was counted at every 3 day in a week. The number of plants twigs attacked, leaves attacked and the number of leaves perforation was also recorded.

\subsection{Data collection from the experimental field}

The following data were collected from the experimental field of yard long bean.

- Number of Aphids

- Number of twigs

- Yard long bean (number \& weight)

\subsection{Statistical analysis of data}

The observed values were statistically analyzed by RCBD. Mean values were adjusted by one way ANOVA and the significant leaves was tested by Duncan's Multiple Range Test (Duncan, 1951) (P < 0.05) using standard software.

\section{Results}

\subsection{Effect of botanical pesticides on yard long bean plant branches}

The study investigated the plant branches of long yard bean, which are significantly differed among the botanicals and control treatments. The mean number of plant branch was significant $(\mathrm{P}<0.05)$. The highest

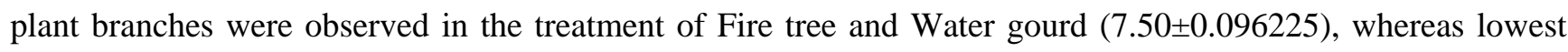
plant branch was observed in the control treatment (4.25 \pm 0.209718$)$ (Figure 1).

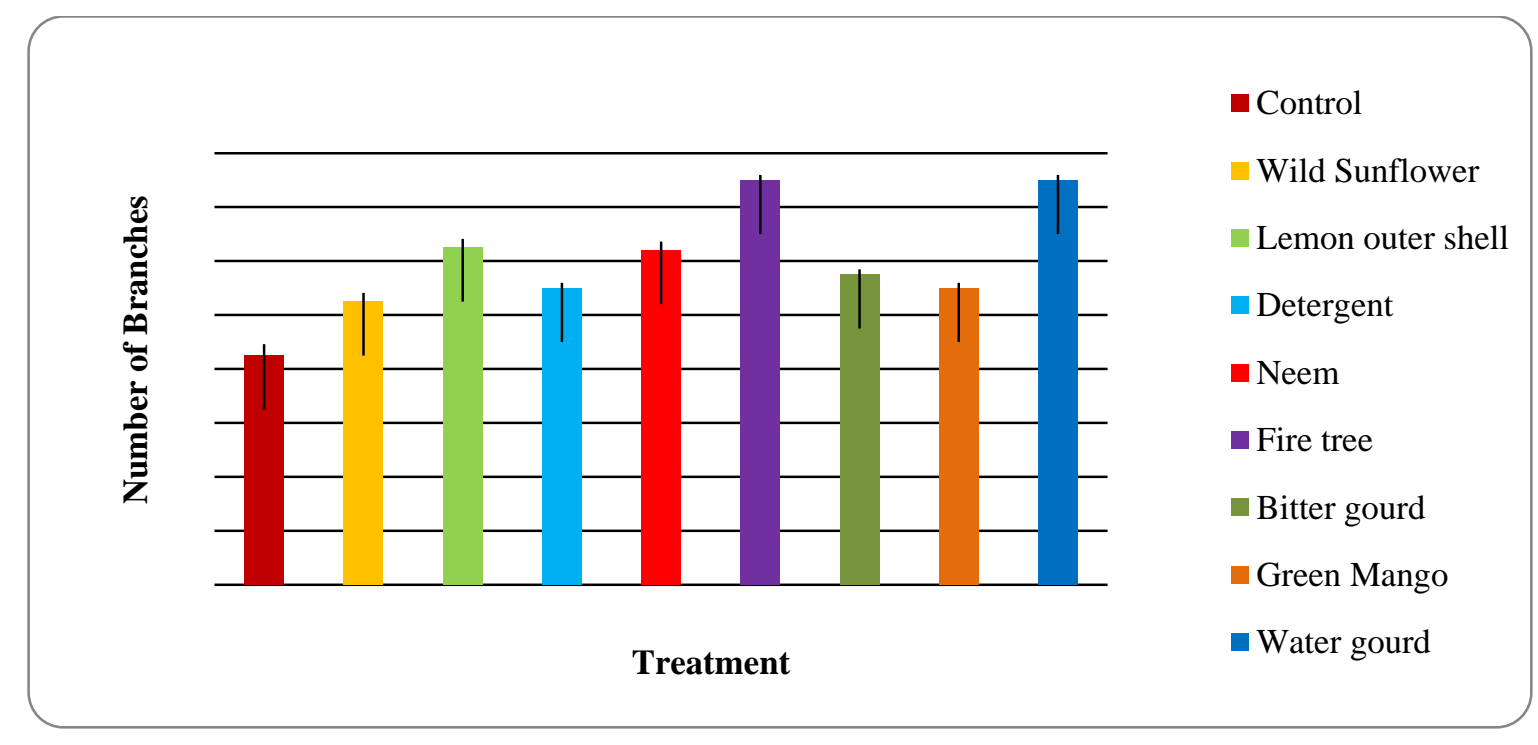

Figure 1. Effect of botanical pesticides on yard long bean plant branches.

\subsection{Effect of botanical pesticides against aphid attack on yard long bean twig}

Aphid attacks on yard long bean twig decreased significantly $(\mathrm{P}<0.05)$ with the application of botanical pesticides. In this study, fire tree (2.00) and water gourd (1.98) treatment showed best performance against aphid attacks on the plant twig. Where as a high number of aphid was found in control treatment (23.57 \pm 0.968052$)$. The application of green mango (2.32 \pm 0.105833$)$ and wild sunflower extracts (3.64 \pm 0.211667$)$ also showed better protection than detergent and lemon outer shell against aphid (Figure 2). 


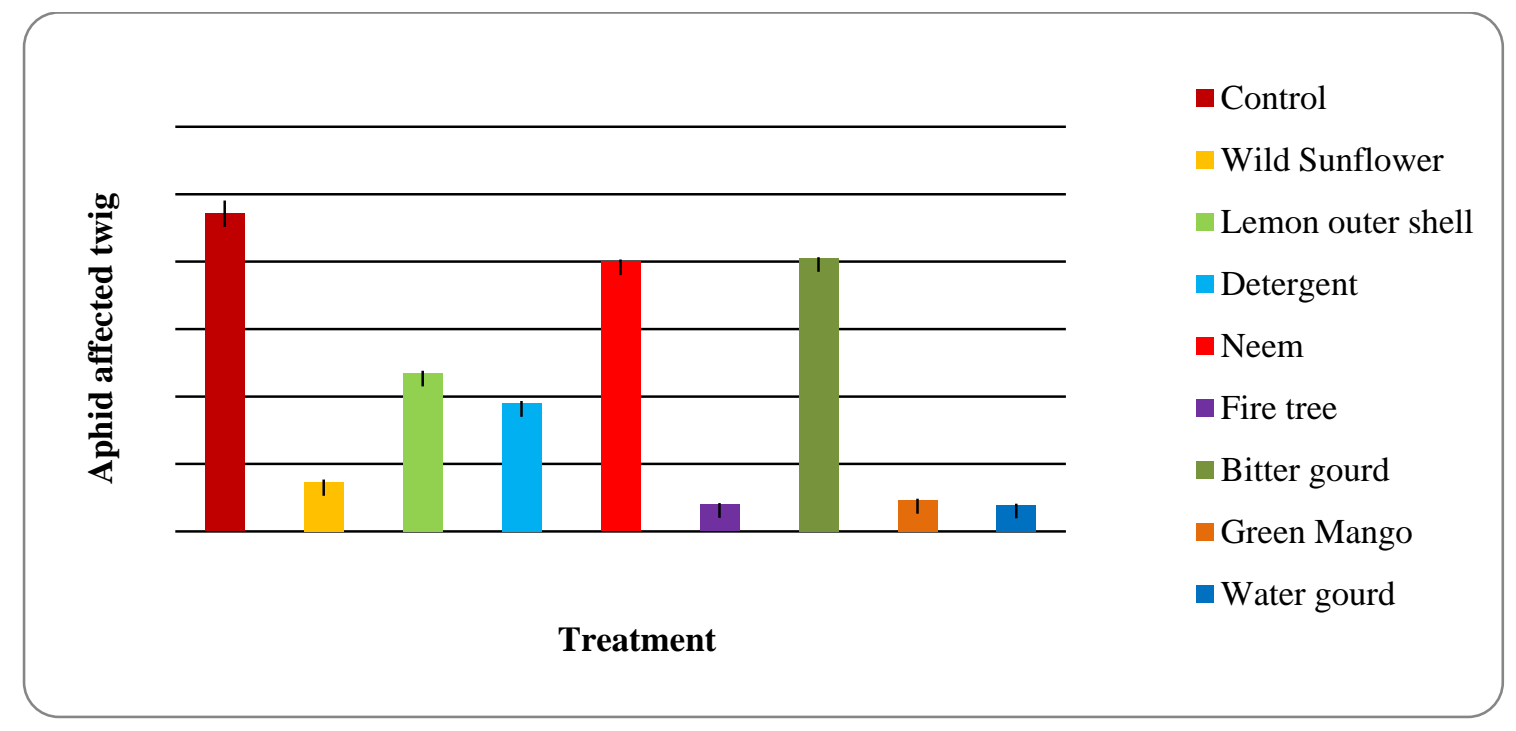

Figure 2. Effect of botanical pesticides against aphid attack on yard long bean twig.

\subsection{Effect of botanical pesticides on the yield of (number) yard long bean}

The study investigated the total number of beans per plant of yard long bean, which was significantly differed among the botanicals and control treatment. The mean number of bean per plant was significant $(\mathrm{P}<0.05)$. The highest number of bean per plant was observed in water gourd treatment $(42.50 \pm 1.456149)$ and the second highest number of bean was in the treatment of fire tree, while the least number of bean was in control treatment (21.75 \pm 0.629153$)$ (Figure 3).

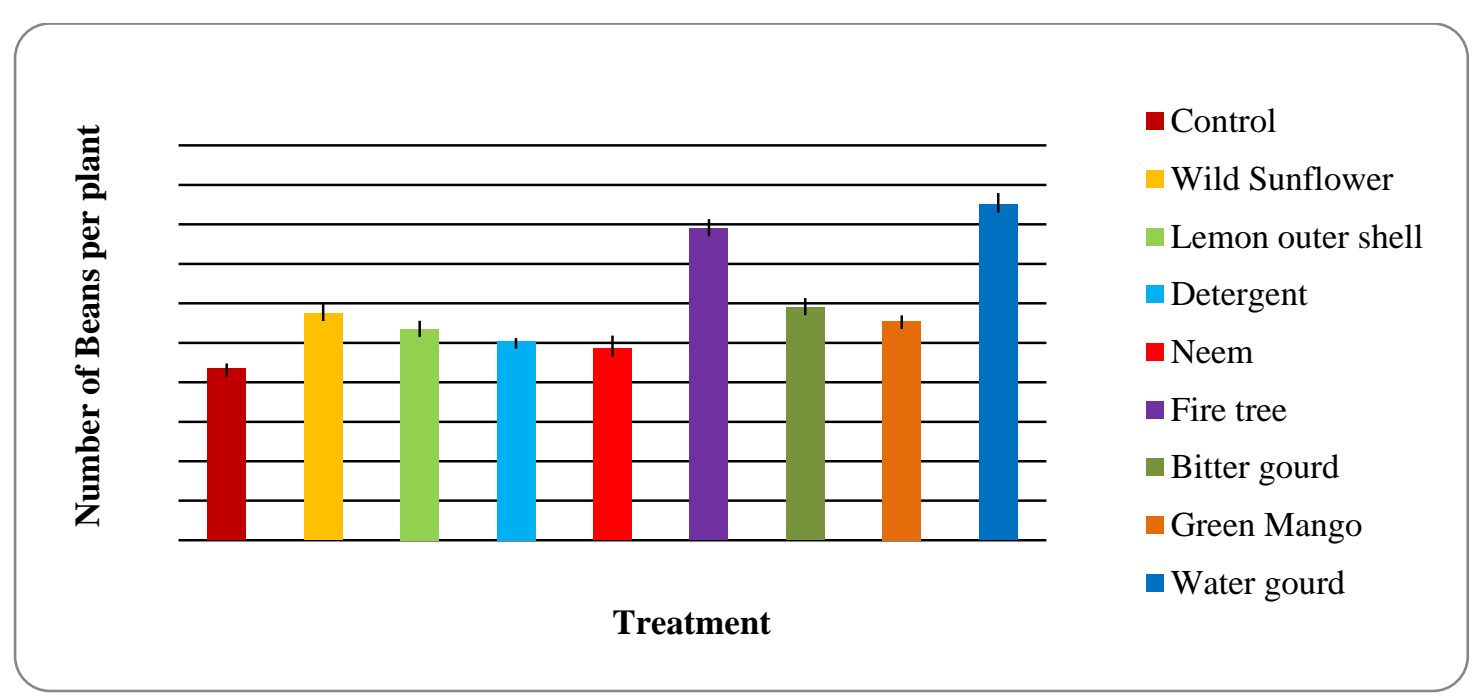

Figure 3. Effect of botanical pesticides on the yield (number) of yard long bean.

\subsection{Effect of botanical pesticides on the yield (weight) of yard long bean}

The study investigated the bean weight of yard long bean, which were significantly differed among the botanicals and control treatment. In case of yield, it was very clear that among the tested botanicals, water gourd treatment $(541.75 \pm 40.21179)$ produced highest production of bean, whereas a lowest production of bean produced in the treatment of control (157.75 \pm 6.64493$)$ (Figure 4). 


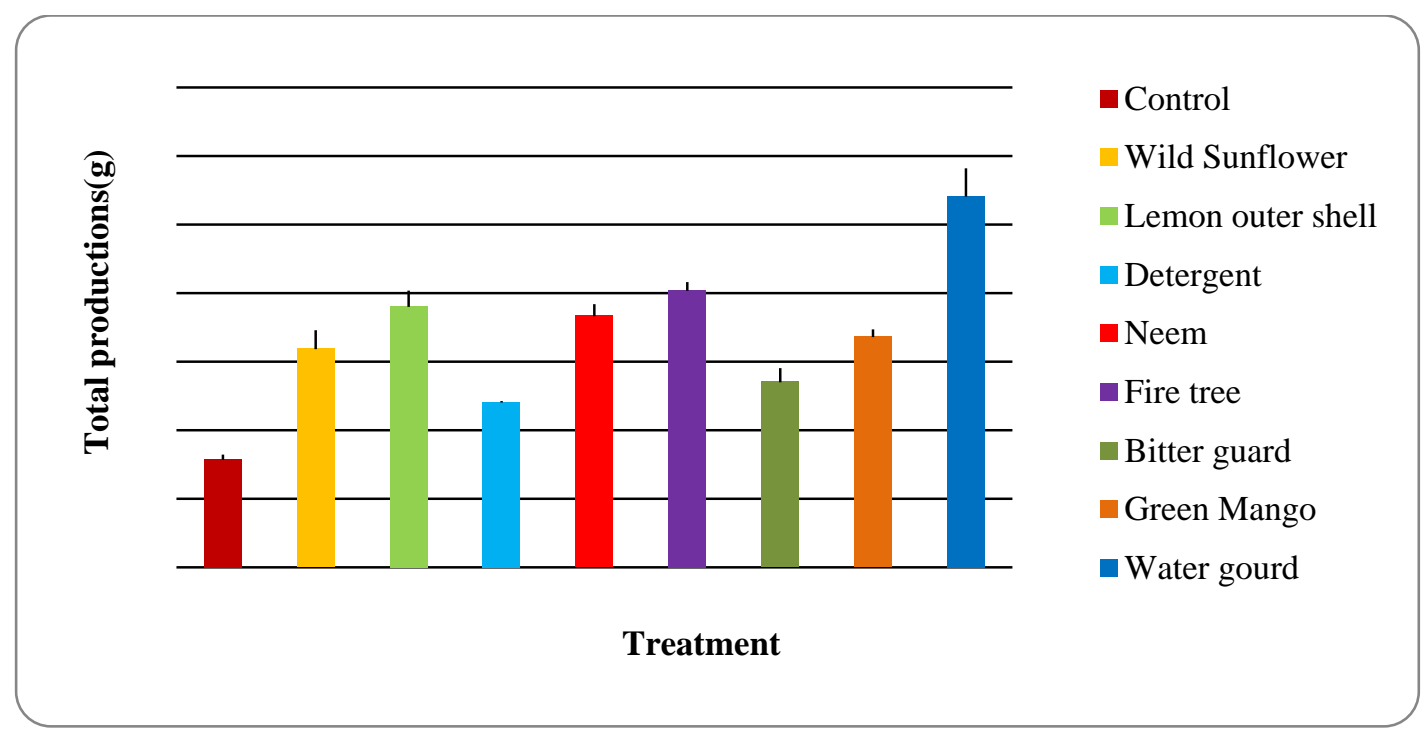

Figure 4. Effect of botanical pesticides on the yield (weight) of yard long bean production.

\section{Discussion}

The present study indicated that different botanical extracts had significant effects on number of bean leaves attacked by insects/pests, number of bean leaves perforation, aphid attacked and number of insects as well as bean production. Results of this study found significant effect of botanicals on aphid of yard long bean. The extract of water gourd showed best protection against aphid of yard long bean. Whereas a high number of yard long bean leaves attacked by aphid was found in control treatment (23.57 \pm 968052$)$. In this study, aphid attacks on yard long bean plant/stem decreased significantly $(\mathrm{P}<0.05)$ with the application of botanical pesticides. Fire tree and water gourd treatment showed $95-98 \%$ control against aphid attacks on the yard long bean. The insecticidal property of botanical extract has long been known and well documents against various insect pests including aphids (Pedigo, 2002). Saikia et al. (2000) reported that leaf (10-50\%) and seed kernel (5\%) extracts of neem caused different effects of bean aphid. Bahar et al. (2007) reported that tobacco leaf extract reduced about 74-90\% aphid mortality on yield of yard long beans. Khare CP (2007) found that aqueous and ethanol extract of flowers were used against round worms. Several investigators found that water gourd and fire tree have alkaloids, phenolic compounds terpinoids, flavonoids and tannin which is as self-defense against pest and pathogens (Rajan and Jeevagangai, 2009); Suresh and Nagarajan, 2009; Irudayaraj et al., 2010; Paul et al., 2011; Madhumitha and Saral, 2011). So, the results of the study were in agreement with the observation of above authors.

The study also investigated the bean production, which was significantly differed among the botanicals and control treatment. From the yard long bean production results, it was very clear that among the tested botanicals, water gourd treatment $(541.75 \pm 40.21179)$ produced highest production of bean, whereas a lowest production of bean produced in the treatment of control (157.75 \pm 6.64493$)$. Mwanauta et al. (2015) reported that the use of agronomic, biological and botanical practices to be a promising strategy in controlling legume pests in the field. Subedi et al. (2018) reported that several plant leaves extract were used as alternative of chemicals to control bean aphids. The results of the present study were agreed with the results of above authors although some botanicals were different.

\section{Conclusions}

Out of seven botanical extracts, fire tree and water gourd extracts showed good results for aphid control in yard long bean. The extracts of fire tree and water gourd ensure that $98 \%$ aphid control and provide highest yield of yard long bean. So, these plant extracts can be used instead of toxic synthetic pesticides for eco-friendly management of aphids. Farmers are advised to avoid toxic chemical pesticides and use botanical pesticides as water extract of water gourd and fire tree for the control of aphid in yard long bean and to ensure quality and safe food for the consumers.

\section{Acknowledgements}

This study was conducted at Institute of Environmental Science, University of Rajshahi under the financial assistance of National Science and Technology (NST) fellowship awarded for the year 2017-18 [Grant number- 
39.00.0000.012.02.009.17-474], Mphil $1^{\text {st }}$ year, Serial no. 17. The authors are grateful to NST for financial support and successful completion of this study.

\section{Conflict of interest}

None to declare.

\section{References}

Annonymous, 1991. Recommendation of the symposium on resources for sustainable agriculture; The use of neem and other plant materials for pest control and rural development, neem symposium. XV11 Pacific Science Congress (Honolulu; East-West center), 1-11.

Anonymous, 2013. Krishi Diary (in Bengali). Agriculture Information Service, Khamarbari, Farmgate, Ministry of Agriculture, Dhaka, Bangladesh, $73 \mathrm{p}$.

Ano AO and CI Ubochi, 2008. Nutrient composition of climbing and prostrate vegetable Cowpea accessions. Afr. J. Biotechnol., 7: 3795-3798.

Bajpai NK and VK Sehgal, 2002. Efficacy of neem, karanj and tobacco formulations against Helicoverpa armigera (Hubner) in chickpea crop. Indian J. Entomol., 62: 21-23.

Bahar MH, MA Islam and MJ Uddin, 2007. Effectiveness of some Botanical extracts on Bean Aphid Attacking Yard-Long Bean. J. Entom., 4: 136-142.

Duncan DB, 1951. A significance test for differences between ranked treatment in an analysis of varience. Virginia J. Sci., 2: 171-189.

Grubben GJH, 1993. Vigna unguiculata (L.) Walp. cv. group Sesquipedalis. In: Siemonsma, J.S. \& KasemPiluek (Editors). Plant Resources of South-East Asia No. 8. Vegetables Pudoc Scientific Publishers, Wageningen, The Netherlands, 274-278.

Irudayaraj V, M Janaky, M Johnson and N Selvan, 2010. Preliminary phytochemical and antimicrobial studies on a spike-moss Selaginella inaequalifolia (hook. \& grev.) Spring. Asian Pac. J. Trop. Med., 3: 957-960.

Khare CP (Ed.), 2007. Indian Medicinal Plants-An Illustrated Dictionary. Springer, New York, USA, 205-6.

Mwanauta, W Regina, M Kelvin, Mtei, A Patrick and Ndakidemi, 2015. Potential of controlling common bean insect pests (bean stem maggot (Ophiomyia phaseoli), ootheca (Ootheca bennigseni) and aphids (Aphis febae) using agronomic, biological and botanical practices in field. Agricultural Sciences, 6: 489-497.

Mariajancyrani J and G Chandramohan, 2013. In vitro antioxidant potential of Delonix regia leaves. Scholars Academic Journal of Pharmacy, 6: 468-471.

Madhumitha G and AM Saral, 2011. Preliminary phytochemical analysis, antibacterial, antifungal and anticandidal activities of successive extracts of Crossandra infundibuliformis. Asian Pac J. Trop Med., 4: 192-195.

Pedigo LP, 2002. Entomology and Pest Management Princeton and Hall Incorporation, London.

Paul raj K, V Irudayaraj, M Johnson and D Patric Raja, 2011. Phytochemical and anti-bacterial activity of epidermal glands extract of Christella parasitica (L.) H. Lev. Asian Pac. J. Trop. Biomed., 1: 8-11.

Rashid MA, 1993. Shabji Biggan (in Bengali), Bangla Academy, Dhaka, Bangladesh, 394 p.

Rajan S and TJ Jeevagangai, 2009. Studies on the antibacterial activity of Aegle marmelos-fruit pulp and its preliminary phytochemistry. J. Basic Applied Bio., 3: 76-81.

Subedi B, K Acharya and K Kafle, 2018. Effectiveness of plant leaf extract on black bean aphid (Aphis Fabae Linn.). Innovative Techniques in Agriculture, 2: 395-399.

Saikia P, D Das and L Saikia, 2000. Evaluation of botanicals and fish oil formulation against bean aphid, Aphis craccivora Koch. J. Agric. Sci. Soc. North-East, India., 13: 79-80.

Sadek MM, 2003. Antifeedant and toxic activity of Adhatoda vasica leaf extract against Spodoptera littoralis (Lepidoptera:Noctuidae). Journal Applied Entomology, 27: 396-404.

Suresh SN and N Nagarajan, 2009. Preliminary phytochemical and antimicrobial activity analysis of Begonia malabarica Lam. J. Basic Applied Bio., 3: 59-61.

Thaker BS, R Verma, A Patibunda and RR Rawat, 1984. Chemical control of aphid, Aphis craccivora (Koch) on lentil. Indian Journal of Entomology, 4: 103-104.

Talukder FA and OE Howse, 1993. Deterent and insecticidal effects of pithraj, Aphanamixis polistachya against Tribolium castanium in storage. J. Chem. Eco., 19: 2463-2471.

The Wealth of India,2004 A Dictionary of Indian raw materials \& industrial products, CSIR,New Delhi III, 1619. 